\title{
Kilka słów o początkach kina bulgarskiego
}

\author{
Грозев Александър, Киното в България. Част I (1897-1956), \\ фабер, Велико Търново 2011, 485 s.
}

Nakładem wielkotyrnowskiego Wydawnictwa Faber w 2011 roku ukazała się książka wykładowcy Państwowej Akademii Sztuki Teatralnej i Filmowej w Sofii profesora Aleksandra Grozewa Киното в България, obejmująca okres rozwoju kina bułgarskiego od 1897 do 1956 roku. Wobec znikomej liczby opracowań monograficznych dotyczących historii bułgarskiej kinematografii, która dotychczas, z konieczności, była omawiana jedynie skrótowo, a często tylko przy okazji kreślenia powszechnych dziejów kina (np. dwutomowa praca Todora Andrejkowa История на киното, tom pierwszy wydany w 2007 roku, tom drugi w 2004 roku, czy История на световното кино 1945-2000 pod redakcją Władmimira Utiłowa i Nadełcza Milewa z 2008 roku), pozycja Grozewa wydaje się wyjątkowo wartościowa. Znakomicie uzupełnia takie publikacje, jak opracowanie Aleksandra Janakijewa Българско кино.Енииклопедия z 2000 roku czy wcześniejsze dzieło Petyra Kyrdżiłowa o charakterze filmograficznym Български игрален филм (1911-1948) z 1987 roku oraz Galinki Genczewеј Български игрален филм (1948-1970) z 1988 roku.

Zgodnie z tytułem, studium Aleksandra Grozewa przedstawia nie tylko historię bułgarskiego filmu, lecz, sięgając do roku 1897, ilustruje również okoliczności, w jakich doszło do pierwszego na ziemiach bułgarskich pokazu filmowego 27 lutego 1897 roku w Ruse. Autor ukazuje drogi, którymi wynalazek braci Lumière trafił i na stałe zagościł w kinoteatrach powstałych w Bułgarii, wówczas od niedawna cieszącej się wolnością. Dokładnie opisuje wydarzenia i okoliczności towarzyszące powstaniu pierwszego filmu fabularnego - komedii Българан е галант z 1915 roku, w roli głównej 
z Wasiłem Gendowem, przyszłym „filarem” kina bułgarskiego. Opierając się m.in. na wspomnieniach pionierów kina oraz informacjach czerpanych z prasy wydawanej na początku XX wieku (np. „Театрални вести”, „Киножурнал”, „Кинозвезда”), Grozew charakteryzuje produkcje filmowe oraz prezentuje aktorów, twórców i producentów kina niemego. Historia bułgarskiego kina została przez autora wpisana w wydarzenia o charakterze społeczno-ekonomicznym i polityczno-kulturalnym czasu kryzysu, który nastąpił po przegranej II wojnie bałkańskiej i I wojnie światowej.

Wiele uwagi poświęca Grozew kolejnemu etapowi w dziejach kinematografii - pojawieniu się filmu dźwiękowego, którego pierwszej projekcji towarzyszył swoisty wyścig rozgrywający się pomiędzy ówczesnymi kinami sofijskimi. Rywalizację wygrało kino Павеч, które 20 marca 1930 roku wyemitowało seans Моята любов не умира, co stało się impulsem do (początkowo zresztą nieudanych) starań twórców o stworzenie bułgarskiego filmu dźwiękowego. Za jedną z pierwszych, zakończonych sukcesem, prób Grozew uważa obraz Wasiła Gendowa Бунтът на робите z 1933 roku. Początek lat czterdziestych XX wieku, opisany przez autora bardzo skrótowo, to okres produkcji filmów propagandowych, realizowanych dzięki pierwszej w dziejach państwa fundacji Българско дело, która dysponując funduszami, mogła wpływać na treści przekazywane przez obrazy. Więcej uwagi poświęcono w książce kinu niezależnemu, rozwijającemu się bez dotacji.

Przewrót polityczny, do którego doszło 9 września 1944 roku, stał się prawdziwą rewolucją także w bułgarskiej kinematografii. Zmiana ustroju doprowadziła nie tylko do poważnych przemian w procesie realizacji filmów, ale także odcisnęła się na ich ideologiczno-społecznym charakterze. W sposób uzasadniony Aleksander Grozew opisuje rozwój bułgarskiego kina socjalistycznego, o którego powstaniu można mówić od czasu uchwalenia 5 sierpnia 1948 roku nowych przepisów dotyczących kinematografii, co stanowiło następny etap rozwoju bułgarskiej twórczości filmowej. Autor na podstawie dokumentów politycznych i materiałów prasowych oraz tekstów programowych kreśli kontekst historyczno-polityczny i kulturowy, ściśle związany z nowym upolitycznionym rozdziałem w historii bułgarskiego kina. Widocznym efektem tych przemian była premiera pierwszego zrealizowanego za państwowe pieniądze filmu Калин Орельт w reżyserii Borisa Borozanowa, 20 marca 1950 roku. Grozew szeroko omawia 
pierwszą produkcję o tematyce antyfaszystowskiej - Тревога Zacharego Żandowa z 1951 roku, która jednocześnie zapoczątkowała nowy nurt w dziejach bułgarskiego kina. Socrealistyczna kinematografia reprezentowana jest w monografii m.in. przez obrazy Димитровградичи Nikoły Korabowa i Duczo Mundrowa z 1956 roku oraz Утро над Родината Antona Marianowicza i Stefana Syrczadżijewa z 1951 roku, a także filmy zawierające główne wątki tematyczne bułgarskiego kina pierwszej połowy lat pięćdziesiątych XX wieku.

Aleksandrowi Grozewowi udało się przedstawić dynamikę rozwoju rodzimego kina, począwszy od działalności miłośników dziesiątej muzy - amatorów (którzy, mając głównie doświadczenia teatralne, starali się zaszczepić na bułgarskim gruncie tę europejską nowinkę, wierząc w jej możliwości i czyniąc wszystko, aby wnieść własny wkład w rozwój europejskiej kinematografii), aż do czasu pełnej profesjonalizacji twórców oraz aktorów.

Atutem publikacji, obok analizy licznych filmów (głównie fabularnych, ale także kilku dokumentalnych i animowanych) oraz prześledzenia rozwoju bułgarskiej kinematografii na tle przemian społeczno-politycznych w okresie od 1897 do 1956 roku, jest umieszczenie - po rozdziałach zamykających prezentację dwóch zasadniczych okresów rozwoju bułgarskiego kina (cezurą jest rok 1944) - biogramów najważniejszych twórców (reżyserów i scenarzystów) w Bułgarii, które uzupełniają informacje o zrealizowanych przez nich obrazach. Monografię dopełniają kadry z omawianych filmów, fotosy oraz reprodukcje dokumentów. Poważnym mankamentem opracowania jest jednak brak bibliografii dotyczącej historii bułgarskiej kinematografii, choć autor bardzo chętnie posługuje się cytatami z różnych materiałów źródłowych, znajdujących się jedynie w przypisach. Monografię zamyka indeks opisanych filmów oraz indeks twórców bułgarskiego kina, których działalność została w niej zaprezentowana. 